\title{
Vaginal Suppository Dosage Form
}

National Cancer Institute

\section{Source}

National Cancer Institute. Vaginal Suppository Dosage Form. NCI Thesaurus. Code C68990.

A suppository intended for administration within the vagina. 